University of Louisville

ThinkIR: The University of Louisville's Institutional Repository

Electronic Theses and Dissertations

$12-2004$

\title{
Approaching Dionysus : challenges of a post-modern Bacchae.
}

Julie Dingman Evans

University of Louisville

Follow this and additional works at: https://ir.library.louisville.edu/etd

\section{Recommended Citation}

Evans, Julie Dingman, "Approaching Dionysus : challenges of a post-modern Bacchae." (2004). Electronic Theses and Dissertations. Paper 413.

https://doi.org/10.18297/etd/413

This Master's Thesis is brought to you for free and open access by ThinkIR: The University of Louisville's Institutional Repository. It has been accepted for inclusion in Electronic Theses and Dissertations by an authorized administrator of ThinkIR: The University of Louisville's Institutional Repository. This title appears here courtesy of the author, who has retained all other copyrights. For more information, please contact thinkir@louisville.edu. 
APPROACHING DIONYSUS: CHALLENGES OF A POST-MODERN BACCHAE

\author{
By \\ Julie Dingman Evans \\ B.F.A., Western Kentucky University, 1993
}

\begin{abstract}
A Thesis
Submitted to the Faculty of the

Graduate School of the University of Louisville in Partial Fulfillment of the Requirements

for the Degree of
\end{abstract}

Master of Fine Arts

Department of Theater Arts

University of Louisville

Louisville, KY

December 2004 
APPROACHING DIONYSUS: CHALLENGES OF A POST-MODERN BACCHAE By

Julie Dingman Evans

B.F.A., Western Kentucky University, 1993

A Thesis Approved on

November 22,2004

By the following Dissertation Committee:

Dissertation Director 
DEDICATION

This thesis is dedicated to the memory of My dear Dad

Mr. Kendall Irving Dingman, Jr.

To whom I owe my life and deepest love And to Professor David Palmer

To whom I owe great friendship and kindness May their sweet souls Rest in Peace 


\section{ACKNOWLEDGEMENTS}

I would like to thank those people without whom this thesis would not exist. First, I want to thank my thesis director, Dr. Rinda Frye, for taking over the direction of a thesis that has been seven years in the writing, and for her persistent encouragement and guidance, which made me believe that I could finish after all. I would like to thank Professor James R. Tompkins, for innumerable lessons learned during my time at University of Louisville, many of which are slowly sinking in, and for agreeing to serve as a committee member along with Professor Julia Dietrich, whom I also thank sincerely for her time and input. My thanks to Professor Albert Harris, who directed The Bacchae and did everything he could to help me find my way in playing the truth of Dionysus and make the production a positive experience without compromising his vision. Thanks to Courtney Kerr of University of Louisville's Graduate School for help with formatting, and thanks to Bronwyn Evans for her time and editing advice. I am thankful to all of the members of the University's faculty, most particularly David Palmer for his generosity of spirit and constant encouragement, Jhanna Gurevich (costumer) for her patience 
and commitment to excellence, Michael Hottois for being the most laid-back Chair ever, Lorna Littleway for opening our minds and teaching us to have eyebrow cocked at all times, and Steve Schultz for demanding greatness and daring me to dig deeper and go farther than I knew I could. I owe a huge debt of gratitude to Mr. William P. Bradford III for teaching love and respect for the art and for expecting nothing less than true attention. I fondly thank my three brothers for their love and support, as well as all the dear friends I have made along the way. I am indebted to my mother for her love, her generous spirit, her inspiring optimism, her constant blessings, and her unflagging faith in my ability to live up to my potential. Finally, I thank my husband, Ben for making me write the thing, seven years after the fact, and for helping me all along the way. 


\section{ABSTRACT}

APPROACHING DIONYSUS: CHALLENGES OF A POST-MODERN BACCHAE Julie Dingman Evans

November 22,2004

This thesis is a personal examination of the process of creating, developing and portraying the character of Dionysus in University of Louisville's 1996 production of Euripides' The Bacchae. It begins with an examination of my acting process prior to study at the University of Louisville and focuses on learned skills which enabled me to meet challenges that I faced coming into this role. The latter part of this thesis examines the effect of my process on the outcome of the performance of the role.

The five chapters of this thesis cover my approach to acting from the start of my career, through University, focusing on the thesis role, and it ends with my conclusions and application to my present work as a professional actor in New York. Chapter One addresses my first stage experiences, my first lessons at the University of Louisville and my struggle with stage fright, and lists what I believe to have been my strengths and weaknesses as 
an actor coming into the role. Chapter II describes my personal process for discovering how to approach character and specifically addresses these challenges: playing a role of opposite gender and sexual ambiguity, working with a movement and vocal style that was completely foreign to my formal training in University, and interpreting a contemporary translation of classic ancient Greek text through heightened delivery. Chapter Three details a seven-day mandatory workshop in Suzuki movement implemented as part of the style of the piece as per director, Bert Harris' vision, and includes excerpts from my personal journals from that period and throughout rehearsals. Chapter Four focuses on the challenges of the actual performance, specifically the full facemask and costume, and stage fright. Chapter $\mathrm{V}$ details how this role addressed the specific acting challenges listed at the end of Chapter I as well as the effects my acting process had on the development of the character of Dionysus, as per this production. 
TABLE OF CONTENTS

DEDICATIONS

ACTING PROCESS PRIOR TO ROLE OF DIONYSUS. .1

Choosing the Thesis Role.

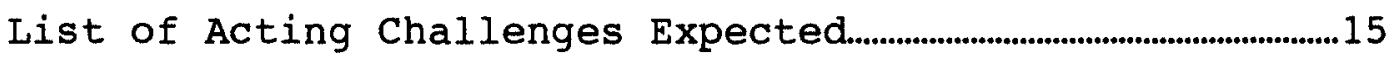

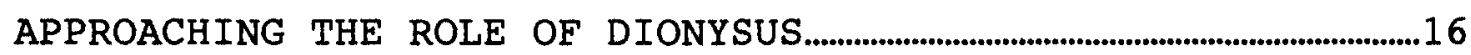

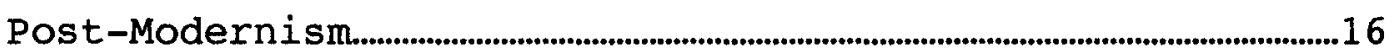

Personal Approach to Developing the Character............................19

EFFECT OF REHEARSAL ON CHARACTER DEVELOPMENT..................................28

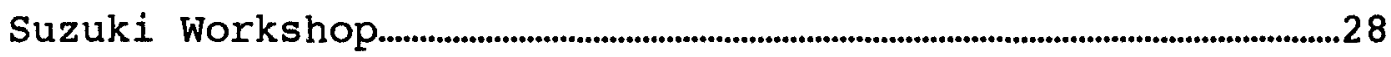

After the Workshop - Rehearsals Begin........................................................35

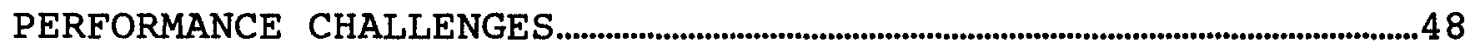

Masks and Costumes Introduced................................................................4

Journal Entries From Performance............................................................56

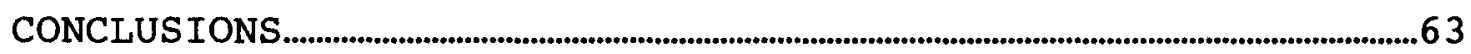

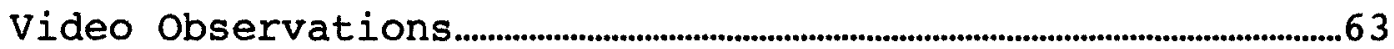

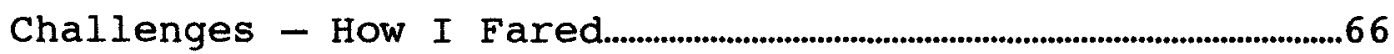

Going Forward: My Process Since the Role.........................................75

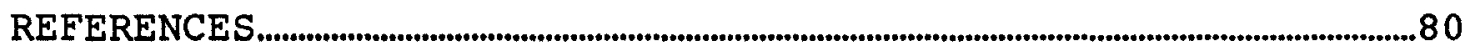

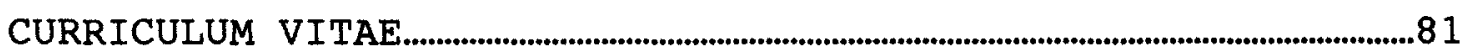




\section{CHAPTER I}

ACTING PROCESS PRIOR TO ROLE OF DIONYSUS IN THE BACCHAE

When I was twelve, I took my first acting class. I was quite sure that I already knew how to "act," in much the same way that I was quite sure I already knew how to ride a horse, though I had actually only dreamt that I had done so. Acting, to me, meant being "real," expressing real feelings, and meaning what you say, as did Melissa Gilbert when she played Laura Ingalls on Little House on The Prairie. To my disappointment, I remember coming away from that first class annoyed at having to mime such mundane things as brushing teeth, putting on boots, and kite-flying. I also felt frustrated at failing what seemed to be the simplest of exercises: "Be sad." I remember when my turn came. I approached my teacher, filled with such unbelievable sadness that I thought surely he might cry, feeling how hurt I was. Our eyes met. I thought I could see him taking in the depth of my sadness. Then he shook his head and said, "Sad. Not mad. Sad." I could not believe my ears. There was something wrong. How was it possible that I could feel so sad and he could not feel my 
sadness? Three times we went through this exercise and three times I got the same unbelievable instruction, complete with my teacher's imitation of my frowning countenance which I am sure got only darker with each passing try. The more I tried to force sadness, the madder I must have appeared. I felt so confused. Only later did I come to understand why the task our young teacher had assigned us was difficult - He had not given us a concrete, accomplishable goal. "To be sad" is a state, not an action. For a long time after (and occasionally still) I would mistake emoting for acting.

A few years later, when I performed in my first show, I felt nothing but joyful. I was thrilled to be onstage helping to tell the story, and unafraid of making mistakes or forgetting lines. I had no thought for how many people were in the audience watching, but only for the intense eye of our director, Mr. William P. Bradford, whose voice boomed from the shadows of the back row. He taught us to listen intensely and to move and speak with purpose. Concentration was rewarded with respect. I acted instinctually, naturally paying close attention to everything happening onstage, and never judging my "performance," except by Mr. Bradford's standards. Perhaps it was because I was still so young that I was effortlessly 
able to tune into the alternate reality of the play and to take risks. Perhaps much of my childhood imagination was still within my reach. Fortunately, I was not asked to play any parts that demanded more scope of human experience than I had already encountered or was able to imagine easily. I now suspect that my beloved Mr. Bradford was more careful than we knew to choose shows with very clear character needs or intentions so that a beginning actor or a child could easily find them. Still, when it came time to play Nancy in our production of oliver, I asked my mother to take me to the used bookstore to find a copy of the Charles Dickens book. In my desire to know as much as I could about my character, and inhabit her fully onstage, I read every word Dickens wrote about her. This proved invaluable. Watching the video of my juvenile performance some 20 years later, I was surprised not only by my apparent lack of self-consciousness onstage, but also by the depth of character I seemed to have achieved almost effortlessly. I marveled at the simplicity of my young performance and was eager to find such naturalness again.

I attended Western Kentucky University as an undergraduate dance major. I spent most of my time in dance classes, but was fortunate to spend my extracurricular time performing in a steady stream of 
mainstage plays. While as an actor I naturally became more relaxed working onstage so consistently, I also noticed what I thought were some bad acting habits forming. I began to listen to myself onstage and I did not always like what I was hearing. I felt myself lose focus. I became distracted by the sound of my own voice "singing" Shakespeare. I began to learn lines musically or by rote instead of for intent. I was, as I have heard many actors say of giving a less than stellar performance, "phoning it in." Then, something happened during Les Liaisons Dangereuses that has colored my stage experience ever since. I was completely in character as the conniving Mme. Merteuil, waiting for a fellow actor to say his next line. I listened with the condescending disinterest characteristic of Merteuil, and, after waiting for what seemed an eternity, the actor I had been waiting for said my line for me. I was dumbfounded. I had no idea that we had all been waiting for me. For the remainder of the run of that show, whenever I wasn't on stage, I was in the wings, script in hand, going over my next scene in a panic. Thus began my struggle with stage fright. I no longer felt that I could trust myself to act on instinct. For every show after that one, my performances felt more and more studied and less free - practiced rather than real and 
present. I left my undergraduate career wanting to study to become "real" again and get back to the source of good acting. This desire brought me to graduate school at the University of Louisville.

The gaps in my acting "process" became immediately apparent when the plays I took on were more complex and the characters' needs not so obvious. Many contemporary characters are written somewhat vaguely, and I did not understand the importance of making my own strong choices for the character and filling in the subtext between the written lines.

This was made clear in the very first acting class of our first year. Dr. Rinda Frye divided the class into pairs and gave us simple "contentless" scenes to work on without supervision for a few days before bringing them back to class for criticism. To her dismay, we returned to class having constructed lives and histories for our characters, but not a single objective or action to serve as the motivating force for the scene. We were all fairly embarrassed by her disappointment and hurried home to include some objectives. When we brought our scenes back to class, we had to admit that not only were they much more dynamic and interesting to watch, but acting in the scenes was much easier. Why hadn't we thought of that? I believe 
the answer to that question is that, in life, people are not always aware of the intentions behind their actions. We often do things we later regret and ask ourselves why we did them. The old adage "Think before you speak" exists because human beings are reactive as well as thoughtful. I was surprised to find that making these choices for a character was imperative. I did not automatically make subtext choices when playing a character, and, unless I considered and analyzed my character's objectives scene by scene, I sometimes would not come up with motives at all. I would simply try to "play" my character "realistically," which is about as vague a choice for an action as exists. Once I realized that there were always objectives underlying my actions, whether conscious or not, I began to look at approaching character study in a different way. Acting with objectives is easy because concentrating on accomplishing a task takes the pressure off of having to "act." This point became even clearer when I began teaching acting to non-majors. In teaching acting to students who had never seen a live production, much less acted in one, I found that giving the students a goal to work for in the scene was often the only way to approximate any kind of naturalness, especially in scripted scenes. When dialogue proved impossible to deliver in a natural 
way, scriptless improvisation with clear, opposing

objectives proved to be the very best tool. I believe that since the students did not have to "act" through the filter of how the character would behave, but were asked only to respond to a given situation as they themselves would respond, they were able to do so. For new students, the idea of thinking as the character caused too much internalizing. Their acting was then intellectualized and their actions did not seem truly motivated by thought or need. I realized that teaching acting to beginners requires first and foremost a clear objective. Once the intent is understood and digested, other directions may begin to be added.

For example, in a very simple beginning acting exercise at WKU, half of the actors in class were put onstage and told to "look interesting," while the other half watched from the audience. After a few long minutes of self-consciousness for the actors onstage and discomfort for those in the house, those onstage were told to "count the chairs in the first three rows of the audience." Suddenly, they appeared dynamic and interesting. Their self-consciousness disappeared as their focus was removed from themselves, and applied to a tangible task. Likewise, the audience's focus was freed, enabling the spectators to 
watch the actors' discoveries unfold. In the context of the class, the lesson made perfect sense, but I found that assimilating the concept into my work onstage would take a bit more time.

My first show at the University of Louisville was Present Laughter by Noel Coward, directed by the late David Palmer. My character, Liz - British, a bit clever, wry, and charmingly fearless - was quite enjoyable to play until the day we moved into the theater. I had no issues whatsoever during rehearsal. I knew what my character wanted and how she would get it. I relished the rehearsal process. However, the moment we set foot on the stage, I panicked. The set seemed tiny and cramped, and I suddenly felt like I was sandwiched between the edge of the stage and the audience. I felt disoriented, was worried that I might fall off the stage, had no faith that I knew what was coming next, and was filled with the overwhelming fear that I would become paralyzed by panic. This fear seemed particularly irrational considering how comfortable I had felt up until the day we moved into the theater. Nevertheless, I existed in a state of semi-terror for the entire run of the show. I sat backstage on the steps of the set with my book in my hands and went over my lines incessantly before each and every scene. No one ever knew 
how afraid I was. I never missed a line or a beat. I was always smiling, always where I was supposed to be, and always on time, but I was terrified nonetheless.

I was cast in three more plays during that first year and, interestingly, my experiences were vastly different in each. While performing as Ruby in the musical comedy Dames at Sea, I marveled that I experienced no stage fright whatsoever. Playing Shelby in Steel Magnolias, I became fully aware of my breathing and learned to consciously relax onstage in the middle of a scene. I was curious that my stage fright seemed not to follow any patterns that I could identify. I did not notice feeling more or less afraid whether playing comedy or tragedy or whether playing in front of large crowds or small ones. The panic appeared irrespective of whether or not I could see the audience clearly, or how many lines I had. Though I kept my anxiety to myself, it seemed only a matter of time before I might become unable to control a flood of panic, which I feared would surely consume my brain in the middle of some important scene. I remember telling Professor Steve Schultz in his Performance Theory class that I was afraid of acting without simultaneously observing myself because I feared that getting totally immersed in the emotion could cause me to lose control. "And then what would happen?" he 
asked. I did not know the answer. But, three shows later it happened.

During the Wednesday night preview of Burn This by Lanford Wilson, in front of a full audience, I experienced the actor's nightmare: I completely "blanked" in the middle of my character's opening three-minute monologue. I had no idea where I was. I stood frozen like a deer in headlights and stalled for time, making up my own lines and restating the last idea I had uttered as many ways as I could until, finally, one of the other actors remembered the thread of my narrative and saved me. Then, an interesting thing happened. Once the scene was moving again, I had to backtrack and reinsert important information that had been omitted during my "blackout." This was a complex task that required searching my brain for lost information while simultaneously saying lines of new exposition, yet I was remarkably undaunted. The fear that had gripped me vanished as quickly as it arrived. I forgot to panic, as I now had to focus on finding a solution to a problem. I was shaken, but interested to fill in the information that had been left out, and I did so without fear of failure.

After the show, Professor Palmer approached me with concern. "What happened?" he asked. I had no answer. He 
had seen me going over my lines in the dressing room just before curtain. "You are not allowed to look at that script again for the run of the play!" This seemed a strange request to me. What might forgetting my lines have indicated if not a need to go over them? Much like during Present Laughter, I had no qualms about the material going into production. I knew my lines. I had studied them religiously. Had I over-studied? I don't believe so. Rather, I think that I had studied incorrectly. I had studied words instead of story. I had learned lines instead of through-lines.

Unlike Liz' needs in Present Laughter, Anna's needs in Burn This were unclear to me. From studying Anna's words in the play, I knew only that she was admittedly confused, and totally unsure of what she wanted. I approached the character believing that, as an actor, my being as confused as the character would be the most truthful way to play her. I did not place importance on making bold her objectives or "raising the stakes" for her needs in the play. I now believe that not focusing on a story or a clear objective allowed my momentary memory lapse. I had only memorization of words to guide me, and that proved to be not enough. I had yet to learn the importance of 
following not only my own character's through-line but also the through-line of the entire play.

The opportunity to apply this lesson arrived the following year, in the graduate acting program's touring repertory company, where I learned a great deal about circumventing stage fright by focusing on the story being told. Here, classics are pared down to their essentials in a one-hour edited form that can be presented in a single period at schools and other public institutions as part of an educational outreach program. Because of the amount of material edited and the time constraints, I was very aware of the challenge of conveying the heart of each story to the audience. It was the first time that I can remember making a conscious effort not only to learn my lines but also to study the through-line of the entire play and to make sense of it in its entirety.

Whereas in the past, I concentrated solely on my character's scenes and function in the story, I now studied all of the characters, and the dynamics of each scene. To discover why each scene worked, I asked and found answers to my own questions, such as "What dynamic is the playwright describing in this scene?" I called my mother and performed the plays for her over the phone, putting the stories in my own words, and playing all the characters' 
parts in the hopes of solidifying my understanding of them. I did experience butterflies our first trip out, but for the two years I worked with the touring repertory company, I can honestly say that stage fright was not a concern. I attribute this to a previously unplanned conscious objective to get the entire story across to the audience, first and foremost, and also to the fact that our characters had, like those from my earliest years of performing, clear intentions.

\section{Choosing the thesis role}

The only role that I ever seriously considered for my thesis, or approached any of my professors about, was Abbie in Eugene O'Neill's Desire Under the Elms. I had been obsessed by the play ever since I chose it for my final project in playwriting analysis class at WKU. Out of all the plays that I read that semester, Desire Under the Elms terrified and touched me to such an extent that I chose to spend the last few weeks of school studying the way that play was constructed. I believed that the role of Abbie would be incredibly challenging for me for several reasons, not the least of which was my tendency to hold on to emotions or play an emotional state as opposed to having real emotions rise and fall spontaneously as a result of onstage action. Though it 
intrigued me, I was terrified by the idea of going to such an emotional peak onstage. I knew that I would be taking a huge risk emotionally to reach the depth of pain required and that I would not be able to go to that depth every night without seriously testing my natural inclination to take the easy way out. In short, I could not "fake" this role.

Much to my dismay, this play was not meant to happen in my third year of University. When I had suggested the project to David Palmer in my second year, he said that the play was much too dark, and offered to submit Small Craft Warnings or Suddenly Last Summer by Tennessee Williams. Then, when neither of these plays made the next year's roster, I faced the choice of either the role of Fay in Joe Orton's farcical play, Loot, or the role of Dionysus in The Bacchae. Bert, who was directing The Bacchae, had told me that he was thinking of casting Dionysus experimentally, with a woman who could play the god as a truly androgynous character. I found this idea interesting and chose to play Dionysus, believing that the role would be more of a challenge for me personally, especially since I had never played a major character in a Greek play.

Approaching the role of Dionysus, I believed my greatest assets as an actor were: 1 . an innate sense of musicality fostered by years of studying violin and vocal performance, 2 . 
a strong, clear and expressive speaking voice, 3. a strong, supple and expressive body from five years' intense dance training as an undergraduate, 4. comfort expressing both masculine and feminine energies, 5. good emotional availability, especially an immediate accessibility to anger, and 6. inherently expressive sensuality.

I felt that my general challenges as an actor were to: 1 . to relax, 2. to hear fully, 3. to be an open channel and react naturally to stimulus, 4 . to be completely aware at all times during a scene, 5. to confront stage fright, 6. to economize, and fight the tendency to push or force moments, 7 . to avoid the tendency to take myself too seriously, 8. to focus on intent and not be carried away by finding the musicality of the phrasing, and 9. to avoid playing a quality. This last challenge proved to be by far the most relevant of all of my general issues as an actor in approaching this role. 
CHAPTER II

APPROACHING THE ROLE

The fundamental focus of the acting program at the University of Louisville is Stanislavski-based realism. Thus, for the three years I studied there, the majority of my performances were based on that realism. However, after reading The Bacchae and the director's pre-production notes, I knew that realism was not the way to approach the character of Dionysus. My job was to work within the parameters of the script, the story, and the director's vision in developing my approach to the role.

Our director, Bert Harris, wanted the style of the Production to be unfettered by the traditional methods of playing Greek drama. For this reason, I believe, he chose a contemporary translation of the text by Kenneth Cavender and adopted "Post-Modernism" as the style to best present his vision. Initially, upon reading Bert's prepared "Preliminary Preproduction Notes," I found the nature of Post-Modernism conflicting and difficult to grasp due to its rejection of a sense of cohesion. For example, in an excerpt Bert quoted from KEY CONCEPTS IN COMMUNICATION AND CULTURAL STUDIES, Post-Modernism is defined as being: 
...committed to modes of thinking and representation which emphasize fragmentations, discontinuities, and incommensurable aspects of a given object, from intellectual systems to architecture...It prefers montage to perspective, intertextuality to referentiality, "bits-as-bits" to unified totalities.

Later in this same passage, however, I was pleased to recognize a correlation between some of the ideas described and what I perceived to be the overall theme in the Bacchae - that of breaking free from the rigors of structure and traditionalism and giving in to freedom of expression. KEY CONCEPTS goes on to say:

...[Post-Modernism] delights in excess, play, carnival, asymmetry, even mess, and in the emancipation of meanings from their bondage to mere lumpenreality.

This sentence provided as clear and fitting a description of Dionysus' nature as I had yet found, and I was encouraged that the style would benefit and help illustrate our story. Bert's notes also included descriptions of Post-Modernism from several other sources. The following selection came from the PRENTICE HALL GUIDE TO ENGLISH LITERATURE :

...post-modernism resists the very idea of boundaries. It regards distinctions as undesirable and even impossible, so that an almost Utopian world, free from all constraints, seems possible. 
A final description from THE HARPER COLLINS DICTIONARY OF SOCIOLOGY further affirms this idea:

Post-modernism...is seen as involving an end of the dominance of an overarching belief in scientific rationality and a unitary theory of PROGRESS, the replacement of empiricist theories of representation and TRUTH, and increased emphasis on the importance of the unconscious...

At the same time that these definitions of Post-Modernism seemed almost to mirror Dionysus' mission within the play itself, I wondered if Post-Modernism did not present an inherent challenge, since, by definition, it seeks to abandon a sense of unity. Could a Post-Modernism-based performance of The Bacchae juxtapose disjointed pieces against each other and still end up with a cohesive whole? Bert's vision for the production extended to the actors as well. On p.4 of his preproduction notes, he described the "acting style" he was trying to achieve:

The principal characters - wearing full face masks, as ancient Greek actors did - will be trained in, and asked to base their performances on, Japanese "Suzuki System" techniques: notably still, formal, MASSIVE, large scale. At the same time the Chorus - wearing smaller, lighter, more form-fitting "mobile" masks - will be trained in African dance, with its quick, energetic, free movement. The two styles - neither of them "Greek" - wouldn't ordinarily "go together." But, in Postmodern terms, both are extreme; both can be "quoted"; and each one will make an ironic stylistic "commentary" on the other. 
Intrigued by the weeklong Suzuki movement workshop

Bert had planned for the cast, I proceeded to read The Way of Acting, The Theatre Writings of Tadashi Suzuki. In a passage on p. 20, Mr. Suzuki defines the goal of the movement style he originated:

What I have developed is a kind of physical "grammar" for actors in performance, based on my own ideas...

...This grammar, the way of using the feet, has been developed around the differences in sensations felt by the body as it connects to the ground. The goal is to ensure and enrich the histrionic unification of the whole bodily expression along with the speech; both these elements are constructed on the basis of the feet. The actor can thus have a different sense of existence on the stage than he does in ordinary life; he need not confront his body or his stage language in any feigned or empty fashion; both can function as one. In the fullest sense, he will have his feet on the ground.

I was enthusiastic about learning this new and economical way of moving. I hoped that practicing Suzuki would ground me and teach me profound ways of communicating energy and intent that would prove useful in my portrayal of Dionysus.

\section{Personal approach to developing character}

My character study of Dionysus consisted of minimal

historical research comparing our translation to other interpretations of Euripides' text. Since Bert's goal was to approach this play from a completely unconventional viewpoint, he did not request that I research historical 
ways of approaching the play or the character. My desire to come to the play without preconceived notions likewise kept me from delving deeply into research, and I simply checked our chosen text generally against standard translations I had saved from high school to satisfy myself that the language of our translation was poetic and clear.

As for attacking the text, I began by highlighting and examining Dionysus' words for their intentions. I found that they were quite clear. I underlined anything said about Dionysus by the other characters, and used the descriptions of him to get a mental picture of his physicality, energy and carriage. I also made use of a technique introduced to us by Professor Lorna Littleway called "scanning and scoring." This approach to cold readings (new material) finds descriptive words, active verbs, or words that strike a strong visual image and marks them for special attention. A point Lorna made was that we, as actors, often tended to emphasize too many words, making it difficult for the audience to hear the dynamic of the line. This technique provided me with a vivid map of imagery and landmarks that was tremendously helpful in my making sense of Dionysus' extensive monologues.

I focused next on making sense of Dionysus' function in the story. I was able to identify character motives 
without much trouble, since Euripides very clearly wrote Dionysus' intentions into the text both directly (through Dionysus' words) and reflectively (through the words of all of the other characters). I learned from my readings of Greek Mythology that the function of the gods and goddesses in Greek plays is often to teach morality, either by providing examples of what can happen when the natural balance of human nature is upset or by demonstrating man's foibles in the face of fate. In The Bacchae, Dionysus teaches the importance of accepting human beings' need to experience freedom, pleasure and sensuality. This is played out through the systematic destruction of Pentheus, the character who symbolizes man's denial of his own nature. Dionysus' actions show that the universe will find its balance, whether by instruction or destruction. Here, in Teiresias' words to Cadmus in the first scene, p.10, Euripides makes the point that man may think that he can control the forces but he cannot:

Yes, now you feel those forces at work in you. To them, all our reason is absurd - a joke. There are things not measured in time, They are ancient, Born in us, with their own life. You cannot reason them away. You cannot define them or describe them. Words are powerless to confine them... ...This power demands its due from us all, that is how it lives, But it does not keep score. 
I discovered from examining the text that, rather than being protagonist or antagonist, Dionysus is the catalyst and the vehicle through which Euripides teaches his lesson in The Bacchae.

To approach the acting, I had also to consider the nature of Dionysus' character: an invincible Greek god, the god of wine, a magnetic figure, and great lover of pleasure who exhibits both male and female sensuality. On p.11 of the script, Pentheus describes Dionysus from hearsay:

I am told a stranger has come to my country. Some sorcerer, hypnotist, from the East Curly blond hair drenched in perfume, Cheeks hot with wine, flashing eyes, Irresistible.

At their first meeting on p.19, Pentheus describes Dionysus as he sees him:

Well, Stranger, you have a certain presence. I can see that women would find you attractive. ...Which is why you have come to Thebes, I presume. Long hair, crinkling down your cheeks - it's clear you have never wrestled...Pale skin... You avoid the sun, you prefer the shadows, Where you hunt down love with your handsome profile, yes?

I did not anticipate having much difficulty with Dionysus' androgynous nature. As I mentioned in the first chapter, I grew up a tomboy and have always felt myself to be in touch with both masculine and feminine energies. 
An interesting exercise in Rinda's voice class further fueled my confidence in being able to portray Dionysus as "this thing of doubtful gender" (Pentheus, p.16). Rinda had us read the Folio version of Shakespeare's Othello out loud with everyone in the class switching off parts without regard to gender. What we found was that very often characters came most alive through the vessel of a player of the opposite sex. This applied to both male and female characters and seemed to be true for every one of us, for at least part of the time. This affirmed my belief that as actors we are all capable (or should be) of playing any character, regardless of sex. We are expected to be capable of portraying things we have not experienced. If two of the actor's primary tools are observation and imagination, then a third is the ability to bring the observed world and the imaginary world inside him/herself, find personal connections, and then express that truth to the audience. I believed that I would easily find and represent Dionysus' androgynous, passionate nature while telling his truth.

However, I discovered an unexpected challenge in the fact that since Dionysus is a god, rather than human. His character is not endowed with a bounty of human emotions and, likewise, experiences no emotional journey. Because 
of this, I was puzzled by how to play him without appearing flat. From my personal standpoint as an actor, a great conundrum lay in the fact that the character does not change. He has no struggle; there are no consequences for his actions. There is no way for him to fail to get what he wants. He has no needs. He exists as an "energy" or a force of will, rather than as a fully developed character with complexities and conflicts of interests that spur his actions. I wanted to feel more than righteous rage and revenge for the entire play. It is also interesting to note that Dionysus is considered by some to be the god of joy, and yet, in this play, joy is not expressed as part of the greater message. Unfortunately, without joy, a sense of conscience, remorse, pity, compassion, or loss, Dionysus does not exhibit the complexity of human emotions that I, as an actor, depend on to define a character's arc. I could not give Dionysus conflicted human feelings that were not assigned by his author. Still, I knew that I would have to find some way to identify with his choices and to make sense of them personally, if I were to bring him to life on the stage. 


\title{
DIONYSUS or BACCHEUS
}

\author{
ZEUS' divine child \\ relishes the happy life \\ He loves Peace who sheds happiness \\ Peace who murses admirable youths \\ And gave of the rich and poor \\ He hates those who do not do their best \\ day and wondrous night \\ to live happily.
}

(Eurip. Bacchai 416-426)

DIONYSUS, son of ZEUS and Semele, who was the daughter of Cadmus, is the God of joy. Even if his sphere of authority is both complex and ambiguous he will always be the one that with the Dithyrambous and the dramatic art contributed to create one of the most beautiful and most important achievements of ancient Hellenique civilisation and art: the Theater.

ZEUS prophesied: My son, bringer of a glorious gift, shall plant in the earth the most fragrant fruit of vintage the Allheal my son DIONYSUS Alljoy will cherish the no-sorrow grape and rival

DEMETER. (Nonnos 7.85)

DIONYSUS does not wish people to drink a lot or get intoxicated; he wishes wine to relax people and create an atmosphere of friendliness. God DIONYSUS and wine help people loosen and become more affable and intimate. (Plut. Dinner of the seven wise men 156)

DIONYSUS discovered the wine and taught mankind how to cultivate the vine. Also he brought much land under cultivation. He discovered the drink made out of barley, called by some zythos. In return for all this received most high honours by people. (Diodor. Sic. 4.2)

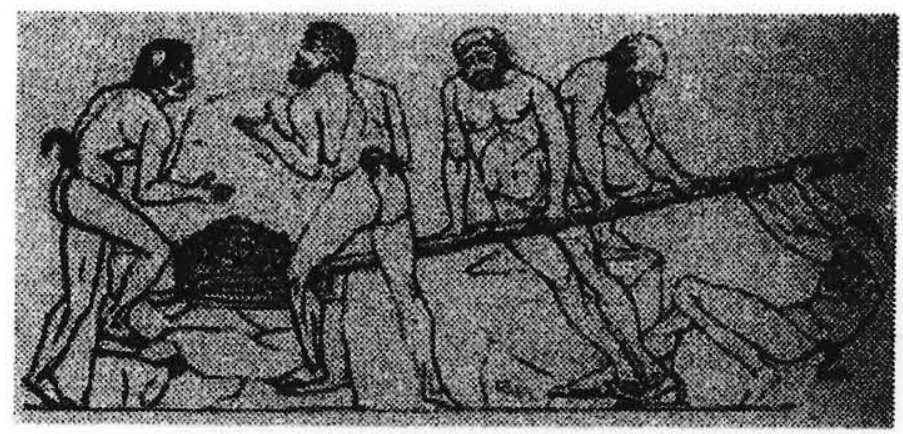

Fig. 1 downloaded Internet image, 1996. web address:

www.addgr.com/wine/dionysus/ukdion.htm

In trying to make familiar, personal connections to

this god character, I compared the nature of Dionysus as

god in The Bacchae to my own ideas about God. I hoped to 
find some parallel concepts that I could use to make strong character choices. On the one hand, I was struck by the very obvious comparison to Jesus Christ- Son of God, son of man, made manifest to save the world's people from turning against the lessons of the gods of the old testament overturning the tables in the temple on seeing that it had been turned into a marketplace. On the other hand, I found that my personal image of God as a compassionate, caring, generous Power was consistent with some definitions of Dionysus that I downloaded from the Internet (see Fig.1, above).

Although I found many parallels to the Christ figure and would use them in my building of Dionysus' character, ultimately, Dionysus seemed to resemble most clearly the alternately giving and wrathful God of the old Testament in the Bible. His actions, and the words said about him by the other characters confirm this dual nature. This excerpt from the Chorus's first "song" describes Dionysus' love and hate:

Dionysus, child of the Universe, come to life In my laughter.

His great love is Peace, lavish with her treasures, Careful of youth.

He hates the man who says no,

No to the day, No to the night, No to life, and no to all love. 
This is echoed later in our script where Dionysus points out:

"And he [Pentheus] will see Dionysus face to face, know that power, know its nature, its gentle, ferocious nature, alive in man, an undeniable god!"

I compared this line to the other translations, and found that they strengthen the idea of Dionysus having a dual nature. The Penguin translation (p. 222):

"And he shall know Dionysus, son of zeus, in his full nature God, most terrible, although most gentle to mankind."

and the Dover translation (p.33):

"Know he must Dionysus, son of Jove, among the gods mightiest, yet mildest to the sons of man."

I hoped that this duality might provide some necessary conflict within the character that would heighten the dynamics of the story. I knew Dionysus had to be very powerful, yet it was important to me that he act on the greatest good for all and not simply on revenge. With that in mind, I looked forward to bringing all of these thoughts and energies into rehearsal and finding a way to bring them to life through this character. 
CHAPTER III

EFFECT OF REHEARSAL PROCESS ON ACTING PROCESS AND CHARACTER

DEVELOPMENT

\section{Suzuki Workshop}

Months before the production, we attended the mandatory weeklong workshop based on the movement style of Tadashi Suzuki of Japan, taught by visiting professor Maria Porter of C.W.Post's Long Island Campus. The workshop took place on a bare stage with a variety of students from different disciplines, many who would be in our production of The Bacchae and many who were not even performers. The days would prove to be grueling and our teacher exacting in her expectations of us. To help illustrate some of what we experienced, I have here included my journal entries from that week.

JOURNAL ENTRIES:

12 oct, 1996

$1^{\text {st }}$ day of Suzuki workshop

Maria is great, I think. I feel ok to trust her with my body and with my head and with my work.

I love that she tells us that the struggle is the beautiful part, how we as humans try to overcome obstacles. Conflict -- that is the beauty of the art. She says that it is good that we don't want to finish the exercises across the 
floor -- and that we Do finish. She says it will be good if tomorrow we don't want to get up for the 9:30 class. "You'll be met with some resistance," she says, "and that is good." I think she means that is how we grow.

\section{3 oct., 1996}

My brain feels overfull. I told Maria that I am afraid I will come back tomorrow and will be much worse.

I am rediscovering how undeniably interesting it is to watch people really focusing on something with intensity. Technically perfect execution is not good theatre unless the performer is fully engaged with their focus on something...

Maria is having us use imagery. Imagine a ray of energy connecting your pelvis to your point of focus - imagine a beam that is connecting you like a magnet to some infinite source; this ray of energy runs through you like a sword. As you change direction, slowly, the ray of energy maintains and is met with much resistance. Once you're facing the new direction, change the focal image.

I confess that I don't seem to be able to conjure up visual images. My brain doesn't seem to want to fasten on anything. Sometimes I try to imagine that there is something "behind that wall" and I am focused on getting to it...but $I$ am embarrassed, and wondering if I am the only one working without a real, clear picture.

One of our core exercises is called stomping, which is just what it sounds like. Knees bent, keeping your center of gravity very low, you stomp your feet hard, alternately. You should have a sense of stomping 1/4" into the floor. Interestingly, stomping seems to promote a sense of groundedness accompanied by a sense of lightness and balance when the exercise is over. I executed a triple pirouette after class without even trying, a feat that I have had to really practice and struggle with to accomplish in dance class. One try and it was effortless, flawless. 
The perfect example of economy: using only the energy necessary to execute.

\section{4 oct., 1996}

Bert says to be aware that as I progress through a given exercise, my "center gets too high." I take that to mean that I tend to straighten my legs too much, and lose my sense of groundedness. Tomorrow I will try to remember.

I am doing better about keeping my arms relaxed.

I must still work on them.

OBSERVATION: Still comparing myself to others in class instead of against "perfection." I am striving for perfection but it seems so far away that I am instead setting for myself what seem more attainable goals, such as letting the tension out of my arms...

Maria says that in the Shakahatchi exercise we should now try to "move as though you are one with the wind." We are not trying to sneak through the air; rather, the air is one with us as we are moving.

New idea to digest:

When the chests are COMPRESSED, the breathing has to happen below-I find this interesting to note, since we were taught in Opera that if the chests are continually EXPANDED, the breath has to fall in below. WHAT TO THINK?

CHALLENGE: Concentrate first on an imagined point of focus. Once that is attained, the next step is to accept the acknowledgement of our intended focus. I received only my second praise from Maria when this finally clicked.

Observation: Focus is much easier when there is a live human across from you that you are allowed to interact with instead of imagined energy.

Observation: Maria keeps her mouth closed whenever she practices Suzuki.

Observation: Something is going on with our teacher; she seems suddenly to be getting quite dissatisfied with what we are doing. 


\section{OCTOBER}

Tonight's session was even worse. One of the girls said that she could hardly do the work because the negative energy was so pervasive. It was weird, our teacher's sudden change from seeming pleased by us, and encouraging, to seeming disgusted by us and unable even to help us. I overheard her talking with one of our regular professors about being unable to cope with our EGOS. What gives? Everyone seems to be working so hard to me!

One of our girls fell tonight during the last set of "walks" across stage. We heard something pop and she collapsed, holding her leg. We stopped then and Maria said that it was a good thing because if she heard that music one more time, she was "going to lose it." (Maybe it wasn't us after all?)

Once the EMS took our fallen student, we continued exercises. Bert observed that I wasn't breathing "from the belly" during the STATUES exercise, so on the next try I paid attention. I realized that I was barely breathing at all; I was, in fact, HOLDING MY BREATH! I consciously let go of that and holding the position was so much easier.

NOTE: On this exercise, anything can happen. We must be ready to change direction or focus at any second. You must be poised, ready to spring. You never know when that stick will come down and you must be ready...

\section{OCTOBER}

Last night was a wonderful experience. We had our Suzuki presentation for a small audience of interested family and friends at the end of our grueling week, and although people were not sure of what they were witnessing, they were nonetheless intrigued.

We gave Maria a bottle of wine and a new stick to replace the old one that she beat to its death on our stage during "Statues." 
Practicing suzuki was difficult. It took discipline to keep doing something that did not feel good to the body at first. There seemed to be no reward for stomping for minutes and minutes on end. I lost patience. Because I longed to see fast results, Suzuki was often as irritating as it was intriguing. As noted in my journal, I constantly compared my "progress" to the progress of others and found myself actively trying to please Maria and Bert. I judged their approval by the number of their corrections (as if I were in dance class where every correction signifies your teacher's unspoken affirmation that you have potential worth training). I wanted to be perfect and to "win" at these games - the stomps, the "walks," the "sitting statues," the "shakahatchi," the "slow ten." I wanted to be noticed for being good or, at least, for having potential.

My favorite exercises were sets of walks that traveled across the floor, in seemingly endless procession. Everyone was to do them simultaneously. The idea was to focus hard on some image, and travel toward it. We were instructed to imagine energy connecting us to the image, while always remaining aware of improving our technique. All of this was "performed" to taped accompaniment of warrior-like music. I liked to pretend that I was 
excelling at these walks, and my friends and I usually congratulated each other afterwards.

Some exercises required a state of constant readiness. In "sitting statues," where we had to be ready to change position the second we heard the crack of Maria's big stick against the stage floor, I noticed an immediate improvement in my reaction time. When my reaction was sluggish, I wobbled or fell out of positions. Sometimes, as noted in the journal, I would unintentionally stop breathing altogether. Because we never knew when Maria's stick was going to hit the floor, we were constantly on our guard, and this, I believe, sharpened our reaction times.

My obsession with perfectionism did not serve me in the week of Suzuki exercises because suzuki follows the premise that one is always striving for, but never reaching, perfection. Neither did my tendency to push my way through life. This tendency of mine, linked to impatience, was brought to my attention several times in Tompkins' movement class when I attempted to force a situation, or make something happen. I remember once, during rehearsals for A Bright Room Called Day, Professor Steve Schultz saying something to me like, (paraphrased) "You cannot muscle your way through this script. You have so much energy and thought but I can just see you flexing 
your chops. You have to let the script do some of the work for you." I often had great difficulty letting things happen. I was fighting against myself, frustrated, not knowing what I was doing and not understanding how any of it was going to apply to playing the part of Dionysus. I felt my concentration wane. My body grew tired with every session and I could feel myself rapidly lose interest if I was not getting many corrections. I had difficulty "seeing" the image we were supposed to be traveling towards or focusing on. At one point, I decided to take heart in the fact that I was at least feeling energy, even if I was having difficulty focusing on something that was not there. I wondered why I was the only one who seemed to have any trouble doing this. I wondered if anyone was on to me but continued the exercises, directing an intensity of energy out of my eyes that I hoped would pass for seeing the object.

Nonetheless, by the time the week was ending, I was starting to feel like I was getting something out of the process, however intangible. While I secretly scolded myself for still wishing for the teacher's approval, I was encouraged by my improved stamina and strength. I could definitely see that I was staying with certain physical tasks longer than I had thought possible, and concentrating 
harder and longer than was comfortable for me. This led me to wonder how much more I might be able to accomplish in many other things if I did not give up so easily - if I pushed myself harder at times. I became aware of my tendency to stay in my comfort zone, and I noticed that when I pushed myself beyond my usual boundaries I was able to see marked improvement. Although I still had no idea what we would do with these exercises in rehearsal, I found in Suzuki movement a power in groundedness and an excellent economy of energy that seemed fitting for the portrayal of a god. I hoped I would be able to use it.

\section{After the Workshop - Rehearsals begin}

I continued my own work, playing with abstract ideas about Dionysus. I kept close the image of the scorned son come to save humankind from itself and that of a gentle breeze able to change at once to killing winds. Physical and sensory images abounded: cats, snakes, kissing, lush green jungles, grapes, lust, flesh, feasts, blood, wine, intoxication, drunk laughter. Along with these abstractions, I culled from my own experiences the passionate intensity of adolescence trying to break free from parental constraints, the urgency of new love bursting, the pride and indifference that makes the body 
languid and the eyes wise, the laugh and stagger that come with brazen drunkenness, the greasy mouth and tight belly from over-feasting, and even that mighty self-righteousness that finds no room for dissent. I heightened the value of bliss, ecstasy, abandon, surrender - by trying to imagine someone taking those things away from me - and there believed I had found a place from which I could call forth Dionysus' rage.

The first week of rehearsals consisted of theater games and improvisational exercises designed to keep our minds off of the text and on the dynamics of the story. Every rehearsal began with the entire cast practicing Suzuki together to restore our energy, clear our minds and focus on the work ahead. Then the Chorus would split off from the rest of the cast for their own rehearsal. Except for the group Suzuki warm-ups each night, I only worked with Eric Soderstrom who was playing Pentheus (the only character with whom Dionysus ever speaks). Our first rehearsals together were quite illuminating. The following excerpt is from a journal entry made during the first week:

Last night, Bert took us into a game that included Eric and myself and Pentheus' soldiers. Since we knew what happens in the story, Bert asked us to act the intentions without any words. Any physicality was possible. At times I felt like a cat and at times I felt like a snake. I had a mouthful-of-canary grin on my face that would not disappear. Eric lunged at me but I 
just kept smiling and let him touch me, which bothered him no end. He wanted to affect me somehow. When he grabbed me, I would kiss him on the cheek or breathe in his ear, drop all my weight or fall into him. He got visibly madder and madder which only contributed to my desire to prick him. I felt like laughing, I felt wicked and mischievous, like a cat toying with its prey. Eric was getting red in the face and frustrated. He pushed the soldiers to take me: I went limp. I felt like I had limitless energy and that I could wear him out just by waiting for him. He was using up all his strength trying to stop me, as if he were trying to stop water flowing by putting a fence around it. I found his journey supremely satisfying to observe, as I was responsible for actively creating it. I realized that the power lay in the fact that Eric was truly giving in to his feelings, to whatever I was "causing" him to feel, and I knew then that because of his openness I could trust him utterly onstage.

I am thrilled. What we are experiencing is real. This is the stuff that I dream of as an actor, this fearless entry into imagination which makes it possible to suspend disbelief and go where you have never gone before. We are risking with each other and yet we feel safe.

Toward the end of the exercise, we were really getting exhausted. The struggle felt like it would never end, much like Suzuki felt toward the end of an exercise, somewhat futile. However, I know, because Dionysus knows, that there is nowhere for Pentheus to go but where I lead him and so I can patiently wait, wait for him to wear down. It is my Truth. As Dionysus, I have endless patience.

In another rehearsal, Bert instructed Eric and me to sit facing each other with our scripts in hand but, instead of reading the dialogue as written, we were to take turns silently absorbing the intention of each line, and then, looking directly into the other's eyes, deliver the essence 
of the line in as few words as possible (preferably one word.) Here is an example of how the script was compressed using this exercise, p.20:

\section{PENTHEUS}

Who are you? Where do you come from? ("confess")

\section{DIONYSUS}

I am no one...But I will give you an easier answer...

I have come across the sea, from Lebanon. ("guess")

\section{PENTHEUS}

And these...practices... Why do you bring them to Greece?

("repulsive!")

\section{DIONYSUS}

Dionysus inspired me. Dionysus. Son of Zeus. ("heavenly!")

\section{PENTHEUS}

So you have a zeus over there, too, Fathering new deities on the world. ("Fraud")

\section{DIONYSUS}

No, zeus fathered the child here, in Thebes, on Semele. ("Powerful")

\section{PENTHEUS}

What is this secret like? Tell me. ("Liar")

Although we were free to take as much time as we needed, Eric and I did not seem to need very much time to find the essence of what we wanted to say. As in the previous 
exercise, both Eric and I were fairly charged by the interaction and the struggle, and looking into each other's eyes had the effect of building an even greater antagonism between us that further fueled the conflict. The greatest benefit of this exercise, for me, was that the feeling under each line became clear immediately. Also, here is where I discovered Dionysus giving Pentheus chances to see his folly and change his mind. Although from the outside it may seem that we were distilling lines down to commands, adjectives and insults, I believe that we pinpointed some important dynamics of the struggle between Dionysus and Pentheus.

I also felt that I learned something very important about action during these rehearsals. In trying to distill all of Dionysus' actions into one, I instead discovered two seemingly contrasting actions. To save is his primary objective - to preserve the natural balance. But, in order to do that he must destroy - his secondary objective and the one that must occur in order for the first to be realized. I reasoned that Dionysus could conceivably have made himself manifest not only out of revenge but also out of love for humanity and, by extension, Pentheus. I pondered that he was actually giving Pentheus a chance to see and to change. My reasoning was that if Dionysus was 
bent on destroying Pentheus, he would not bother to warn Pentheus or give him advice. I chose to believe that Dionysus was intent on making himself known but that he was also willing to teach the lesson as gently as possible. In fact, I found several places in the script where Dionysus appears to be allowing Pentheus a chance to see the error of his ways, as exemplified here in this excerpt, p.37, 38:

\section{DIONYSUS}

I warned you Pentheus, but you would not listen.

I have suffered at your hands - nevertheless

I will give you some advice:

Do not use force against Dionysus.

End the war in yourself.

The god will not allow you to disturb his

Bacchae.

Leave them in the mountains where they are happy.

\section{PENTHEUS}

Don't preach to me. You were in prison and you escaped. Guard your freedom or I will hand down justice once again.

\section{DIONYSUS}

This is an eternal power. You are a man. I would make sacrifices to him, not struggle and rage...

\section{PENTHEUS}

I'll sacrifice to him -- women's blood, And much of it. They deserve it. There will be carnage in the glades of Kithairon.

\section{DIONYSUS}

You will be defeated. Bronze shields will be useless against wooden sticks and women's hands.

\section{PENTHEUS}

Extricate me, someone! How do I get rid of this foreigner? 
No matter what I do he talks!

\section{DIONYSUS}

Sir...this can still be settled easily, Without fuss.

\section{PENTHEUS}

What am I to do? Stoop lower

Than the lowest in my land?

\section{DIONYSUS}

I will bring the women here without the use of force.

\section{PENTHEUS}

I see. This is your offer. One more swindle.

\section{DIONYSUS}

How can you call it that? I want

To save you, I work for nothing else.

This section made clear to me that I could logically choose "to save" as an active motive along with "to teach" and "to get even." After repeated futile attempts to teach Pentheus his lesson in a nonviolent way, Dionysus would have no choice but to purge Pentheus utterly and thus - I decided - save Pentheus" soul, and the "soul" of humanity. In my mind, Pentheus had to become the unwitting sacrifice necessary to restore balance to human nature. I was grateful to have made this discovery.

At home I spent time memorizing lines and working on the monologues by myself, trying out different stresses, inflections and tempos. I tested to see what might happen to the dynamic of a phrase if my voice became suddenly soft 
or if I worked up gradually into a crescendo or if I barked the words. Still, there was only so much I could do without rehearsing with my mates. I played with words, rolling them around in my mouth and experimenting with texture, pitch, color, and tone. The actual memorization came slowly and did not worry me. I noted that I was either becoming quite comfortable with the magnitude of the speech or else I was falling into self-indulgent largesse. I figured that either way, I was all right since I was playing the god of excess. Still, there was only so much I could do without rehearsing with my mates, with the text on its feet.

So far, in rehearsals, I had been allowed the freedom to use my own voice and my own physicality in making my discoveries. However, when the text was actually brought into rehearsal, this changed. Bert was looking for the Suzuki voice and I struggled with the Suzuki vocal ideal. In Suzuki workshop, where we recited text simultaneously in great booming voices while performing some demanding physical feat, I had felt a great sense of power and intention. Barking the text by myself felt like, quite simply, words being yelled. I had an overwhelming urge to make what I was saying sound real, and to use my entire vocabulary of pitch and dynamics to do so. Bert tried to 
help me keep my voice in the lowest register by reminding me to breathe deeply and relax my throat, but I only remember feeling that I had suddenly lost all of the notes in my scale except for those in the very bottom and that I had no idea how to "play the song" with just the "bass."

At this point we were no longer approaching the character from the inside but from the outside. I had had some success in the past approaching characters in this way. For instance, I usually could take a "line reading" from a director and make the change work without having to rethink any interior monologue, even if the change was significant. I found that the interior monologue often would change naturally as a result of the outward change. However, in this case, fitting the character I had been creating into the constraints of the new givens was difficult. As we began to apply the suzuki vocals and movement style that we had been practicing for months during warm-ups (and that Bert had intended for the production) onto the text, I found myself growing more and more unsure of what I was doing. Like my own acting students, I was stumbling trying to play this character through so many filters.

At the end of Chapter I, I outlined what I believed to be my strengths and weaknesses coming into the role of 
Dionysus. One of the strengths I cited - my sense of musicality and rhythm - was offset by a weakness - my tendency to rely on musicality and rhythm instead of finding the deeper truth within a line. I found two comments I had written in the pages of my script to be noteworthy because they addressed this personal trap that would plague me during The Bacchae. They were: "Bert wants to keep the pauses in the rhythm within the speeches but close the gaps in dialogue," and "Bert likes it when the phrasing is more musical than psychological...Rhythms!" I wanted to believe that I could, as in the past, "fix" my delivery to suit the director and have the character still ring true, thus I decided to work harder to perfect the Suzuki voice and stances. I tried to be more aware of breathing deeply and keeping my throat open. I delivered my lines with my knees bent and my center low. I practiced absolute stillness when not speaking. I tried to focus my energy, and find volume, from an imagined center of power below the navel. The struggles that I felt in Suzuki workshop were mild in comparison to the struggles that I now was having, because now an entire performance depended on my "getting it right."

As performance week grew near and I became visibly more frustrated at not being able to produce the quality of 
sound and movement that Bert desired, Bert brought

Professor Tompkins in to assist. Here is a journal entry from that rehearsal:

\section{NOVEMBER}

Tonight we rehearsed with Tompkins and there were some new ideas tossed around. One image in particular I was fond of was the image of Pan. The goat is one of the symbols for Dionysius, so imagining Dionysus with hooves and horns lent the character quite a mischievous bent. We practiced a walk based on that physical idea which was interesting but incongruous with suzuki movement so it was abandoned.

QUESTION: How can something be incongruous in a Post-Modern production?

Tompkins told me also tonight to take the "catty, lounge quality" out of my voice and to take a wider stance with turned out feet, in order to keep the character from appearing too feminine. Is Bert looking for Dionysus to be absolutely masculine? I thought androgynous meant genderfree?

Physically and vocally, creating this version of

"androgeny" became a stumbling block. I was starting to feel angry and to believe that I was basically being asked to leave myself out of the equation for portraying this character. I missed not being able to use any "femaleness." I struggled against the idea of making the character seem strong by extracting all the female qualities. My thought was that if the character were truly androgynous, as Bert professed wanting Dionysus to be, then 
wouldn't we want sometimes to see the feminine side of him as well as the masculine side? Webster's definition of androgeny is "having the characteristics or nature of both male and female!" Yet, both Bert and Tompkins agreed that any physicality that suggested femaleness should be struck from my possibilities of movement for Dionysus. This is not as much a complaint as an observation describing the parameters within which I had to build the character. I wanted to believe that I could really make Dionysus come alive but was beginning to have my doubts about how I would be able to. Discussions were fruitless. Bert was not looking for subtlety in our production. I did not feel that I could argue with what he was seeing/hearing because I had no way of being objective.

\section{NOVEMBER}

Last night was Run-Through, and thank God I started to find Humor again. I am always so surprised when I've been feeling that a role is just not working and then I realize that it is because it has lost all its humor, it is like a tire that has lost all of its air, totally flat and the piece doesn't roll at all.

I admit I am frustrated that I still have not worked at all with the Chorus.

I lament that I was not more specific in this last journal entry regarding where I found the humor or what caused me 
to find humor again. Perhaps something happened in rehearsal or perhaps I just got tired of feeling powerless and negative and decided to find something good on which to focus. Regardless, I do know that I entered Production week with mixed feelings of fear and excitement. There were still a lot of elements that had not yet been put into our rehearsal process: the masks, the costumes, live snakes that Bert planned for us to hold and use throughout the Production, the score (Commissioned of a School of Music Composition grad student, it had yet to be seen.), the African Dance, as well as the logistics of working on the set. I was excited to work with the snakes, but I was worried because I had never been able to rehearse with the mask, or the costume, or with the Chorus, from whom I felt completely disconnected. I was still hoping to bring some profound power to life on the stage and Bert was encouraging but I had my doubts and was concerned that I would not bring anything real to life at all. 
CHAPTER IV

PERFORMANCE CHALLENGES

\section{Production week challenges: Masks/Costumes introduced}

Production week arrived and, little by little, crucial elements were implemented into our performances. Masks and costumes were being made, fitted, re-designed, remade, and refitted. As set pieces were erected onto the thrust stage, our blocking was changed accordingly. Bert became much more exacting in the implementation of definitive physical gestures to support his vision, and he gave me very specific choreography for certain lines or phrases. I had yet to work with the Chorus, and the Chorus had yet to work with the music that they were to be learning. On a positive note, my anxiety about being thrust into an unfamiliar playing area was eased somewhat by being able to observe the set as it was being built. I was grateful for not having to imagine the physical spaces where the scenes would be played.

A dominant aspect of Bert's vision of The Bacchae was the costuming of its characters. Bert was very clear about how he saw Dionysus and Pentheus outfitted, as illustrated 
in this chart included in his pre-production notes (see Fig.2) - The chart was prefaced by his statement that "A strong, bold, clear visual contrast between these two characters is crucial to the interpretation of the show, so I think it best to present my notes on the two of them side by side."

\begin{tabular}{|l|l|}
\hline \multicolumn{1}{|c|}{ Dionysus } & \multicolumn{1}{|c|}{ Pentheus } \\
\hline Image: traditional classical Greek clothing & $\begin{array}{l}\text { Image (armor breastplate); carved Aztec stone } \\
\text { calendar (See "Guards," below) }\end{array}$ \\
\hline $\begin{array}{l}\text { Androgenous (will be played by Julie Dingman, but } \\
\text { we don't want her to seem overtly "feminine") }\end{array}$ & $\begin{array}{l}\text { Hyper-masculine (macho-male type, very excessive } \\
\text { testosterone level in every way) }\end{array}$ \\
\hline Pale colors; earth tones; metallic accent = gold & $\begin{array}{l}\text { Dark colors; black or charcoal gray; metallic } \\
\text { accent = silver }\end{array}$ \\
\hline Curved lines; slender & Straight lines; stocky \\
\hline Soft, flowing fabrics & Leather or heavy wools (arms \& legs) \\
\hline $\begin{array}{l}\text { Face pale/white; sensuous; round/plump/ } \\
\text { curves; full, smiling lips }\end{array}$ & $\begin{array}{l}\text { Face dark/black-gray; prominent square and } \\
\text { powerful jaw; straight/rigid lines; never smiles }\end{array}$ \\
\hline $\begin{array}{l}\text { Blonde/yellow hair ("built into" the mask); } \\
\text { wavy or curly; slightly long, for a man }\end{array}$ & $\begin{array}{l}\text { Hair covered by helmet; or, hair that looks like } \\
\text { it could be a helmet; same color as the armor }\end{array}$ \\
\hline Barefoot, or sandals & Jackboots \\
\hline Seductive; stands for freedom & Forceful; stands for control \\
\hline
\end{tabular}

Figure 2. Costume chart for Dionysus and Pentheus, as submitted in Bert Harris" "Preliminary Production Notes"

I do not know how the other masks were built, but Dionysus' mask began as a standard white plastic mask with two little eyeholes and nose holes and a small horizontal slit for the mouth. Besides cosmetics, the mask had to be 
altered for two immediately obvious logistical reasons: I could not see or be heard out of the mask. Though the eyeholes were enlarged several times in an attempt to rectify the sight issue, this problem was never solved completely. On the video of the preview performance, I quite obviously bowed my head to see as I stepped off the foot-high platform to exit; however, I still misstepped and tripped on my way out. I gave up fighting this issue when, with practice, I learned my way around the space and became better at judging the distance to the edge of the platform and to the chorus members who were often seated there. Basically, I ended up performing without the benefit of much peripheral vision.

In regards to being heard: Since Bert was not willing to consider a half-mask, the issue became how to alter the full mask so that sound had a clear path through which to travel. The mouth-hole was cut to roughly the size of my mouth and a screen was put in place. This partly solved the problem, but only if someone was standing directly in front of me; when I turned my head to the side, my speech was muffled. There remained the issue of clarity. Due to the proximity of the screen to my mouth (there was almost no space between my face and the mask), words sounded garbled. I was sibilating and spitting against the inside 
of the mask; the letters $S$ and $T$ sounded hissed and fuzzy, and all plosives sounded like small explosions. I grew increasingly alarmed because the more I tried to enunciate, the worse the assibilation. I would like to say that this most important of dilemmas was remedied, but it was not.

I remembered when Professor Tompkins' introduced us to "neutral" masks in his movement class. There we witnessed the phenomenon where, with a slight change in the wearer's body posture or gesture, the "neutral" mask would appear to physically change expression. Therefore, a "neutral" mask is also an "expressive" mask. I also remember watching footage of Japanese puppetry in Bert's Theater History class, marveling that the slightest movement could make a puppet's "face" appear to be "feeling" something. To degrees, some of the character masks in our production were "expressive." I would venture to say that mine was not one of these masks. I tried practicing with the mask in the mirror - lifting my chin, turning my head this way and that. But, to me, the mask always looked expressionless. * In performance, I wore an identical mask on the back of my head. I regret that I do not remember exactly why it was put there or when it was added, and I may or may not have discussed its deeper meanings with Bert. Regardless, I believe that I can safely say that its existence did not 
affect my performance in any way. I could not think of any ways to use a mask on the back of my head and I highly doubted its having any expression since there were no eyes behind it.

The costume presented its own challenges. Dionysus' robes and golden curls did reflect Bert's design specs (to be feminine in contrast to Pentheus' very masculine uniform) but, once set on my shape, the overall picture did not seem to sit right with him. Concerned that the character was losing its masculinity, Bert gave instructions for the blond curly wig to be replaced with a shorter brown wavy one. He also wanted to keep the skirt long so that my ankles would remain hidden, but, as I was constantly tripping over the skirt, the hem had to be shortened. As he became even more intent on obscuring the fact that I was female, I was directed to abandon any remaining vestiges of feminine physicality that might give me away. My stances were fixed. Anytime I was not traveling, I was to be standing, legs apart and feet slightly turned out, arms away from body, and head still. No extraneous movements to weaken the position. Now, feeling completely cut off from the core of sensuality that I had originally hoped to bring to Dionysus, I found myself having to turn and face the inevitable - focusing 
completely on the intense energy of voice and physicality that we had been practicing in Suzuki all along. Additionally, I decided to stuff a pair of socks into the crotch of my tights.

I missed subtlety. I missed being quiet. I struggled because, while I knew that strength and energy and power could be conveyed at a very low volume, I could not speak softly or the audience would never have been able to hear me through the mask. That I felt "safe" behind the mask suggested an underlying fear of revealing myself to the audience and was, therefore, both a blessing and curse. The blessing enabled me to relax by alleviating some anxiety, but the curse constructed a literal barrier between myself and the people to whom I was supposed to be bringing the truth of this story. Unfortunately, at the time, I failed to realize this dichotomy and the opportunity it could have provided me. Instead I chose simply to feel lucky for being relieved of a bit of my increasing apprehension.

More anxiety melted the day I first ran the show in my bare feet. I was reminded of dancing and instantly felt a grounded connection to the warm wood floor of the stage. In addition, Bert prescribed for me a determinate physical action to help me center and set up the opening monologue - 
a sharp head turn to the extreme right followed by a laboriously slow turn to the left, taking in all of the audience. I was truly grateful for the time this gave me to breathe, to see, and to focus my energy and thoughts.

However, what centered me and settled my nerves more than anything I could have anticipated - more than any relaxation or Suzuki exercise I had ever tried - was being able to hold the two live ball pythons introduced by Bert just a day or so before the opening performance. Oh, how I loved holding those snakes. I loved feeling the dry coolness of their skin. I loved the steadiness of their gaze, and the grace and perfect economy of how they moved. I loved that they were constantly seeking warmth and that onstage they would sometimes wind themselves into the sleeves of my costume for heat. But, most of all, I loved them for calming my nerves. Maybe it was psychosomatic on my part but all I can say is that holding those reptiles was as good a remedy for relieving nerves as any I had found.

\section{Videotape lessons}

When dress rehearsals began, I asked Bert if I could videotape the show in order to take it home for study. He agreed that taping might be a good idea, and I proceeded. 
I hoped that the camera's eye would provide me with some much-needed objectivity but was surprised at what I saw and disappointed by what I heard. The first thing I noticed was that, as Dionysus, I did not look like a woman, which I reluctantly decided to count as a small victory. I did not sound like a woman, either, but this was no victory. My voice sounded to my ears like someone's poor imitation of a boxing announcer, booming out words in a constant barrage like a gong with a senseless rhythm - no inflection or variation of pitch or dynamics, no reason or feeling behind the words. I was appalled and could not imagine how difficult it would be for an audience member to listen to me droning on in that voice - in what I thought was a masculine register. Just as I had feared, in trying to keep the voice "low" and "supported," I had lost any sense of connection to the text, and it now sounded colorless, dull, and pushed, which is just how it felt. Watching the video made me feel somewhat vindicated, and I determined to add "notes" and "color" back into my vocal approach in the hopes of returning some life and richness to the character. I planned to do this while still trying to follow Bert's advice to use Suzuki breath deep in the belly for power and to relax the throat to prevent undue heightening of pitch. 
As opening night loomed, I began to get excited. Bert was supportive and encouraging about all of the work we had put in so far, and his prediction of success was music to my ears. I was impressed with how some of the costumes had turned out and I especially enjoyed watching sharon's Teirisias and Heather's Agave taking shape. I looked forward to Dionysus' scenes with Pentheus. Eric and I always enjoyed playing together onstage as we had developed a good dynamic and trusted each other completely. The Chorus' songs were finally being implemented, although last minute, and the Pre-show music arrived, moody and intense, and helped me concentrate my energy. We all wanted this to be a powerful show. But, with all the excitement, I was having trouble remembering my lines. As with everything now, I approached this issue from the "outside-in," prescribing myself physical gestures to attach to lines of text that I hoped would help jog my memory were I to become lost. I didn't know what else to do. This is clear in the journal that I kept during the week of performance.

\section{Journal Entries from Performance}

\section{DECEMBER, Tuesday}

Notes from Sunday, First Dress: Nerves, but I believe all the lines were there. I have had to find physical connections to carry me through some transitions in text where I have 
been finding myself lost...because mentally I am not always where I SHOULD be.

This means rehearsing transitions time and again, using some physicality or gesture to cement the sections.

Example: One section of monologue I end with right arm extended, finger pointing, "MAD!

BACCHAE!"

I used a physical choice to connect the end of that monologue to the beginning of the next text, slowly lowering that arm until it was down at my side with finger pointing to the ground for "THIS...is what it means to be half-born..." Note: I will have to practice this transition quite a bit before I am not going up on lines there anymore.

Notes from today's Preview:

Bert approved of the Pentheus monologue where I am holding the Ball Pythons. He said that the monologue is always very clear and that he can see everything as I am describing it. I told him that I thank Lorna Littleway for teaching us "scanning and scoring" of a script in her acting class. Then he said to all of us that there are a lot of things that we can get from our teachers here and that we'll never know when we might be able to use them.

* Note - several students asked their teachers whether or not the actor who played Dionysus is male or female!!!

\section{DECEMBER}

Last night was Opening Night. That was the hardest, getting through the first audience. I told Bert how terrified I was and he said, "Why do you think I gave you that very slow head turn at the very beginning of the show? So you could center yourself for that first monologue..." which does seem to be where most of my anxiety lies.

It is like an obsession, this mad feeling of panic, this stage fright thing. Again, I wonder if it might be better to talk about it less - 
could talking about a fear give it more power, make it more real? Or could talking about it diffuse its potency because it is no longer a secret? I tried talking about it at breakfast this morning, and I think it is getting better. I hope it is.

I have to admit to another thing that really helps my anxiety - personal praise. I feel so encouraged when I am reminded that what I do touches some people. Tonight I felt that the audience was with us from the very beginning, and I was emboldened by that. I wonder if part of stage fright isn't a bit of egotistical paranoia that the audience somehow expects you to fail?

Holding those SNAKES has a tremendously calming effect on me. Sometimes when I feel nervous, I go hold them and instantly feel my nervousness dissolve. They are so cool. On opening night, Melissa Kinney said to me, "Those snakes are going to have a stroke before the end of this from all your freaky energy."

I feel a need to get the focus off of myself. I know that is supposed to be the whole point of relaxation exercises but I am afraid that I will become too relaxed and lose sight of where I am. Yet, I keep hearing that tension and anxiety are what cause an actor to go up on lines in the first place...too bad I don't believe that... I would just like to be able to relax enough so that I am not having to concentrate on what line is coming next and so that every moment feels real to me. -So what is the best way to do this and be right on top of every line? I still think it has to be telling the story.

I wonder if the end of Olivier's stage fright coincided with a particular thing, like doing more film and less theater, or if it just passed?

\section{DECEMBER}

Something funny happened last night. In the last scene I went flying onto the set with my mask off 
- up on top of my head! By this point, not really dealing with stage fright any longer, I laughed and with my left hand flipped the mask down over my face while my right hand, extended, pointed out. "ACCUSE YOURSELVES!" I thundered, while I observed the audience from behind my mask. No one seemed to be overly bothered by my blunder.

Today was a fog for me. I woke up feeling out of sorts and confused, a feeling that worsened throughout the day. I began to worry about the show and to anticipate not being able to concentrate, which snowballed into even more concern for the opening monologue. I asked Bert to help me to get focused during Suzuki warm up, and he spent extra time with me. I had to really work to focus my energy and intent, and to keep my mind from wandering. Sharon Kinnison did an extra "Slow-10" exercise with me after everyone else had left to get into makeup, which was a great help, as was going through the first two Tai Kwan Do forms.

Every single night that we have done this show, I have found a quiet place away from everyone where I am able to sit down and meditate through that opening monologue. Going over that monologue calmly in my mind reminds me that I am prepared.

\section{DECEMBER}

Bert taped the show, for posterity.

Some weird jazz music came on in the middle of a very dramatic scene. I was kind of pissed off, but I tried to channel that energy; I think it was ok.

A friend who saw the show tonight asked me if I was nervous during the first monologue! She said she could tell. It made me wonder: How does my work differ when I am nervous, that she can tell? Then I wondered: Could she tell that I was stuffed? Because I have worn a pair of socks in the crotch of my tights ever since opening and I 
honestly can't imagine playing Dionysus without them.

\section{DECEMBER}

Our two-show day.

Both shows were really good but now it is getting late and I am afraid that I am more than weary. My body is hinting at the first signs of illness. Just one more show to go. Come on, I can last that long. It will be a fine show.

\section{DECEMBER}

The final performance felt glorious, as though somehow powered by Everyone, by the Universe. It was thrilling. I was just as nervous as I was opening night. I prayed and went through Dionysus' first monologue traveling across the backstage in Suzuki "Slow-10", as I have done every night. I reassured myself that when it was time for the words to come out of my mouth, they would be there. I let the gestures come and reminded myself that there is a logical sense to the words and to my movements.

Then, a wonderful thing happened. In the middle of the first monologue, I gave up - the fear, the panic, the anxiety - I gave it up to the Universe and let go of it. At that moment I knew that to be truly present I had to trust myself with the material and let go.

In places where I would feel myself on the edge of panic, starting to wonder about lines that had not yet materialized, my only choice was to ignore the little voice and relax and breathe. The lines were there - sometimes at the precise moment they were leaving my mouth, but they would come. I have to admit that was thrilling.

December 13

Re: Closing night

I had to allow myself to take the time...otherwise I knew I would regret playing every show with some lurking fear, unable to relish many moments onstage. I am happy, but wistful that I was not 
able to give myself that freedom at an earlier stage in the game. Perhaps it was not something that I felt in control of until that last show? Why? I don't know. At any rate, I am grateful to have been able to feel like I let go and let the play play itself. Finally.

* Note: Something changed for me that last show. I felt unexpectedly sad in Dionysus' last scene with the Chorus, holding the snakes, sad and sorrowful. I was filled with christ and Last Supper images, and I kept thinking, "I don't want to leave you but I have to" under all the Iines. The text came out with a unforeseen tenderness that I had never tried, that came from a deep sense of, I suppose, the kind of sadness that comes with having to leave something that you are responsible for, that you love, that you came to help.

Is it possible that my specific sadness - as an actor leaving the world of the play - gave me access to a layer of Dionysus' character that I had only barely acknowledged? Sorrow! Perhaps it would not have been what Euripides intended, but there it was, and it suddenly all made sense.

When The Bacchae closed, the cast members

congratulated each other and deemed the experiment - a Post-Modern interpretation of a Greek masterpiece - a success. The public gave the show mixed reviews. Apparently, much of the text was lost due to the full facemasks. Many audience members felt emotionally detached and did not care what was happening to any of the characters, save Agave in the end. One person stressed a need to find more ways to use the voice and body if the face is not there to help you express. A few members of the audience told me that they found the show very 
interesting and were moved to think; from this I felt a sense of accomplishment. Though I never felt that I mastered Suzuki technique - far from it - I did feel that there was a very real sense of power that affected some audience members despite the obstacles. The idea that we had stimulated some theatergoers with an unusual take on a classic play satisfied me to a great extent. The truth is, I enjoyed every single performance. 


\section{CHAPTER V \\ CONCLUSIONS}

I am writing this thesis in 2004, seven years after playing Dionysus in the University of Louisville's production of The Bacchae. Since that time, I have been working as a professional actor onstage regionally, in National and International touring companies, and in my present home of New York City. I feel very fortunate to have had, and to continue to find, so many opportunities for creative work and so many people dedicated to exploring and making discoveries to deepen our understanding of the craft of acting. My experiences, both in acting and in life, since I left the University of Louisville have only affirmed the lessons that I learned there.

I seem to have a history of learning lessons most fully when I make my own mistakes, and of stumbling repeatedly before recognizing my folly. My experience with The Bacchae was no different. Only now, seven years later, upon deliberate scrutiny and deconstruction of the situation and my part in it, am I truly discovering the choices I made that constituted my "process" for developing the character. The last seven years have provided distance 
and experience with which to determine more objectively how those choices helped or hindered the telling of the story of The Bacchae.

Revisiting a project after seven years can be daunting, but fortunately, I followed the advice that Bert Harris gave me before the project began and made notes in a journal throughout the entire process. Although I was unable to be completely objective about my process or performance in the journals, I was able to gain from them valuable insight into my thought processes and was reminded of where I struggled most. Trying to make sense of my notes and organize them into a linear whole has made me aware of an important opportunity that I may have missed to "raise the stakes" of the character and thereby heighten the emotional connection. I am also becoming aware of my tendency to give up before, perhaps, I should.

\section{Observations}

As I began writing this thesis, I watched the videotape of The Bacchae, which included our Suzuki workshop final and the taped dress rehearsal referenced in Chapter IV. I acknowledge that video has its limitations and does not accurately portray live events, as the recording device used is capable of capturing a mid-range 
of levels but is not capable of capturing either the energy that passes between the actors and the audience or the richness of levels of voice or movement. Those indescribable moments in life which prompt one to say, "Oh, I can't explain it; you had to be there," cannot be preserved on videotape and exist only in the memories of the people who experienced such moments together. This is part of what make live performances so special. That having been said, I still cannot overemphasize how much I value video as a tool for self-analysis. Sometimes seeing and hearing myself through the camera's eye and ear is the only objective picture of myself as I am working that I feel I can trust. Immediately I can see if my shoulders are drooping forward, if I am "leading" with my head or straining my neck, if my hands are flying around, or if I am shifting my weight from foot to foot. In the case of the The Bacchae, I observed what I thought to be a great deal of tension being held throughout my entire body for the whole performance. On video, my motionless stance seemed not at all like a cat or snake ready to strike, as I had hoped, but rather stiff - arms held inches away from my body like a muscle-bound weightlifter who can't put his arms down, legs apart, in the only position deemed acceptably "male," feet slightly turned out, knees bent. 
My movements looked robotic and my voice still sounded pushed and false (although I wrote that I intended to remedy this problem after watching the rehearsal tape.) I also felt that there were other actors who did a better job than I of making the words and lines sound connected in a real and passionate way. As I watched the video, I expected to find myself caring for the characters and the story in the same way that I did in 1997 when we performed it. I was surprised to find myself, instead, having difficulty connecting with the piece due to my total distraction by, and dissatisfaction with, my own performance. Not even knowing and loving the story of The Bacchae as much as I do was enough to move me. From this I conclude that while video can be used as a constructive critical tool, one must remain aware that some of the most important aspects of live performance will be lost in translation, and not base the success or failure of a performance on what comes across on tape.

\section{Challenges - How I Fared}

In Chapter I, I listed what I believed to be my personal strengths and challenges coming into this role. Our production of The Bacchae presented additional 
unexpected challenges and I ended up addressing more issues than I had originally foreseen.

I think Dionysus would have benefited from my face, my voice and my physical expression. As I mentioned early in the thesis, I grew up as a girl who happened to embrace both male and female energies. Therefore, when I was asked to play Dionysus, a role that seemed to require this very balance, I naturally assumed that my own person would be sufficient for the part. Bert did not see the situation exactly the same way. For all my delight in my "strong side," I believe Bert had doubts about its being enough to suspend the disbelief of the audience, doubts which intensified once the rather feminine costume and long curly wig were in place. What resulted was, in my opinion, an unhappy loss of vocal range and physical expression that was painfully evident on the videotape. My mission then became to express this character, an androgynous god, while being fully masked, battling stage fright, tripping over my costume, holding live snakes, trying to remember to breathe from my low belly, losing balance on Suzuki walks that I never quite mastered, and to have it all come from a place of truth. Following, here are my personal challenges and how they were addressed in the face of this considerable mission. 
To relax and alleviate stage fright, I meditated before every show, I held the snakes, I practiced deep breathing, and I prayed. There was a long hallway that led from my dressing room to the stage entrance. Before every performance I traveled the length of that hallway in the meditative "Slow-Ten" walk, breathing deeply all the way. Bert also helped by spending extra time practicing suzuki with me for focus and by giving me definite physical choreography that I could use to help sharpen my concentration in the moment. I did feel some onstage nerves, particularly on opening night. But, I remembered not to hold my breath and I focused on thinking positively, which, for the most part, kept panic at bay. I distinctly remember feeling relaxed and energized onstage. Yet, on the video, this relaxed energy is not apparent, and I seem stiff and forced in my "stance." I found this hard to reconcile. Was this another case of "Sad, not mad...?" Was I in yet another scenario feeling one way but seeming another? or is it possible that the video unfairly extracted all of the intangibles that made the performance riveting to some? Those who appreciated the performance said that their attention never wavered because of the strength of my commitment, that their belief in the power of the story was based on my being present and believing so 
strongly in what I was doing. This leads me to believe that there is great power in believing that what you are doing is "real," and that commitment to whatever choice has been made is key to engaging yourself and the audience. Regarding finding economy/ fighting the tendency to force or push moments: I believe that, had I studied Suzuki for a long time before performing this piece, I would have been more successful in this endeavor. I believe that any physically demanding practice eventually enables one to find and express power in a unique and profound way, but that I had not found that yet in Suzuki. I longed to express power by simply directing and connecting energy through my eyes, the way we had in Suzuki workshop, but I believe that the mask was like a wall between me and everyone else, and that energy coming from the eyes simply did not read as well as it would have had I had my face to express with. I also believe that I expended a great deal of unnecessary energy trying to approximate an outside image of maleness that did not feel true to me.

I respectfully disagree with Bert on the issue of Dionysus' physicality. If Bert wanted Dionysus and Pentheus to be a study in contrasts, as he illustrated in his costume design chart, then why not let Dionysus strike a less stiff and "macho" figure? Why couldn"t Dionysus and 
Pentheus have had contrasting ways of moving through space? Also, shouldn't there have been some harmony between the way the Chorus looked and Dionysus' appearance? The Chorus, a band of Dionysus' followers, is supposed to be filled with the ecstasy of the god, hence their singing and dancing. Yet I, Dionysus, the god of wine and passion, moved like a robot, and boomed like a gong. I feel that Dionysus, more than being powerful and strong, symbolizes freedom, lust, ecstasy, passion and letting go. In my opinion, his physicality should have reflected that more. The restrictive structure of Suzuki did not allow Dionysus to be contrasted with Pentheus in that way, which would have better fitted the meaning of the play.

As for my tendency to take myself too seriously, I think the trap inherent in this role is obvious, and that once I gave up trying to find joy and pathos, it was an easy trap to fall into.

The next few challenges are interrelated in that my meeting them required me to make specific choices that I believe I possibly overlooked. I now believe that I may have taken the words of the text too literally and, as a consequence, failed to see the possibility for choices that could have helped me form a more emotional connection to the work. I mistook choices for discoveries. Dionysus' 
words seemed to have no remorse and so I gave him none. I found motives, but without finding evidence of his having any needs, I did not think it was my "right" or my duty as an actor to assign him any. I mentioned in earlier chapters my desire for Dionysus to have feelings, and my predicament of not finding anything in the text to back that up. Intellectually, I considered the possibility of Dionysus having feelings and how that might inform the scenes where he is trying to save Pentheus. But, eventually I decided that the text did not support his having deep feelings, and so, the furthest I went with him emotionally was to a place of pity - until the very last performance. Why didn't I think I could "raise the stakes?" I thought that I was examining the script and discovering how the text supported or did not support the idea of Dionysus as this angry god who has come to exact revenge. But, I now feel that I made a choice - an interpretation, rather than a discovery. What if I had made a different choice - that Dionysus needs to be remembered, or that he needs to save the world to be what he is? What if I made the choice that saving the world was his destiny and that he was desperate for it to happen? Perhaps that choice would have inspired me to tap into my 
own desire to serve Truth, thereby connecting myself in a very real way to the material.

Perhaps I could have chosen for Dionysus not to know what the outcome was going to be? Perhaps, but since I did not, the challenge of hearing fully became an impossible task. Of course I believe that I heard my fellow actors onstage. Unfortunately, I cannot say that I heard them "fully," because I did not allow anything that was said by anyone else to impact my character. As Dionysus, I heard the words but I already knew what the outcome was going to be. I believed Dionysus had a pretty good idea of what was going to happen in any given situation. This makes for, undoubtedly, a selective kind of hearing.

Furthermore, with regard to being "an open channel," being "completely aware at all times during a scene," and "reacting naturally to stimulus": I found myself in the same position - unable to be truly reactive to what was happening around me onstage because I had chosen that my character was affected by nothing. I chose for him an action that had no obstacles, because I believed that the text supported that. I "found" Dionysus to be in absolute control of everything that happened in the world of the play. Why react to anything? Thus, the "channel" was closed. If I had explored more avenues or followed my 
instincts more closely, I might have well discovered more compelling options.

Finally, I mentioned at the end of Chapter I that perhaps the most important challenge that I anticipated going into this project was the challenge not to "play a quality." I wish I could say that I succeeded in meeting this challenge, but again, for the same reasons mentioned above, I did not avoid this pitfall. Additionally, the style of Suzuki ("notably still, formal, massive, large scale," as Bert describes it, p. 20) required largesse that I did not learn how to make real.

Suzuki was an intriguing and demanding style of movement that I enjoyed learning and practicing. However, I am not surprised that I was never fully able to integrate this system into my performance as Dionysus. I believe that Suzuki, like dance, martial arts, or any other demanding physical study, takes years of practice to master. In my estimation, assimilating a style deep enough into the body so that muscle memory replaces conscious effort takes more time and practice than we had available. I have never seen a production done entirely in the suzuki style, but I can imagine that it could have the power to stir the audience emotionally. I believe that if I had had years of Suzuki training prior to The Bacchae, my 
interpretation of Dionysus through the style of Suzuki would have been informed in a completely different way. I do not want to give the impression that I am ashamed of the work that was done for the production. I am not. I feel that there were some extremely important and very real discoveries made, particularly in rehearsal. There were terribly interesting things discovered in Suzuki workshop as well. I only wish that more of the truth of those discoveries had maintained throughout rehearsal and translated into performance.

Interestingly, if I hadn't had the video to reference, I might be writing completely different conclusions. I would still be noting the struggles of trying to learn Suzuki, the disappointment of losing the element of feminine sensuality, of the burden of a facemask that hindered speech, hampered vision, and hid emotion. But, I would also be declaring something of a victory since the feeling I remember most, the feeling I was left with as the show closed, was a deep sense of satisfaction and accomplishment, based on audience responses both during the show and afterwards. Some people claimed to be truly touched. My journal entries from those last performances were glowing (see Chapter IV, p.62-63), and they are the memories that have stayed with me. It is possible too 
that, had that very last performance been recorded, there might have been something quite interesting and completely different to observe, for the show seemed to change by the last performance and I wrote that I allowed something real to happen with Dionysus that I had not allowed before. I allowed him to care deeply about the outcome, and to feel sorrow. I would like to imagine that, had the run gone on another couple of weeks, I would have come naturally to the conclusions which I have been able to make now with the benefit of reexamination and hindsight.

\section{Going forward: How my process has evolved since the role}

Soon after leaving University, I joined the National Tour of Damn Yankees as a replacement dancer "swinging" (covering) ensemble parts and understudying the lead. I had two weeks to learn the show and then was thrown in with everyone else who had been doing the show for months. I was absolutely terrified that I would make some mistake, and probably did, but had so much to remember that I just kept on going forward until the show was over. Every night I shadowed the lead actress from the wings, mouthing her lines, her songs, and her dances. I studied her scenes for their function in the story and four months later, when I went on as Lola, with only 2 understudy rehearsals with the 
company, I suffered very few nerves at all, though I had never done the role before in front of an audience. When I got scared I reminded myself why my character was onstage at that moment and I did what I knew I had to do. The performance was really fine.

My first few shows in New York City were small, creative productions of Shakespeare plays, which I fully enjoyed. I played Viola in Twelfth Night, Celia in As You Like It, and then the tremendous opportunity arose to play what is, in my opinion, one of the greatest roles of all time. I was cast in The Women's Shakespeare Company's Production of Othello as Iago, a role I had coveted ever since reading aloud from the Folio in Rinda's class some years before. The experience proved to be an unexpected dual opportunity: testing both my own approach to playing a male character and my theory of battling stage fright by learning the entire story.

In approaching Iago, I did not try to affect male mannerisms; I simply allowed what male energy rests inside me to be very present and to inform my actions. The physicality seemed to fall into place naturally. I imagined myself a man and was a man. I did not change my voice, but it did fall into a slightly different place. The difference was that I didn't try to put the voice there 
or manipulate it any way. The voice fell where it fell because it was informed by something very real that I was feeling. Nothing felt forced. Laughter erupted spontaneously; breath spawned thought. Iago was excited about everything, and his lust was palpable. As a result, my Emilia confessed to having developed a huge crush on Iago, though not on me. I considered that to be the highest praise I could have ever received.

The test of my theory of "curing" stage fright by focusing on the story presented itself once I realized that the woman who was playing Othello had several huge hurdles. Not only was this her first time playing a lead character, she had never played Shakespeare before, and, though she was quite literate, English was her second language. She simply did not always understand exactly what she was saying. When, two nights before we opened, she lost lines in Act II and picked up with lines from Act IV, skipping an entire act, I committed to learning every line of every scene we were in together, and to making sure that I was absolutely clear at all times what were the details of each scene. I was never so glad to have done homework in my life. There were nights when I had to say both our lines, nights where I had to prompt her, and one night where I had to bring us back from a later scene she had drifted to. 
Yet, I have no doubt that my Iago was a real and believable portrayal of a man. Two excerpts from off-off Broadway Review's critique of our production read:

The Women's Shakespeare Company is dedicated to presenting the classics with all-female casts, giving women opportunities to play the powerful roles rarely accessible to them in commercial venues...In this production...director sidney Fortner and her excellent cast created such a convincing world that the gender of the performers became a non-issue...

...Julie Dingman's powerful, impassioned Iago was a magnetic presence, maintaining a high level of energy throughout and dominating the stage whenever she appeared...the sword fight [between Iago, Cassio and Montano] was absolutely topnotch, proving that women are more than equal to the physical challenges that these parts demand of them.

I do not believe that my approach to Iago would have differed had I never played the role of Dionysus. I approached the gender issue in Othello much like I had intended to approach it in The Bacchae. However, the certainty with which I stuck to my convictions, playing Iago the way I instinctually wanted to play him, may well have resulted from my experience playing Dionysus. Voices were raised between Sidney (Othello director) and myself and lengthy discussions took the place of half-hour breaks. My own stakes as an actor were far too high for me to accept anything less than my best. In the end, my director and I came to trust each other, and I delivered what I 
still consider to be one of the most truthful portrayals of character in my life as an actor, something I might not have achieved had the experience of the Bacchae not strengthened my resolve to fight for my instincts.

Going forward, I realize that one of my biggest issues as an actor is also one of my biggest issues as a human being: trust. In life and in acting I find myself in a constant struggle, relearning how to trust my instincts, to trust my work and my preparation, to trust the material, to trust that less really is more in most situations. I am learning to trust that if I keep searching I will find a solution, perhaps several. I am learning that thinking out of the box will inevitably provide at least another point of view worth looking into. I am learning that I lessen my options by assuming that the answer is "no" before ever asking the question, and I am starting to become more comfortable with the idea that just because a person is in a position of authority does not mean that person should not be questioned. I am learning that failure is not always the worst thing in the world, and can be an incredibly valuable experience, depending on your perception. I am still today learning the value of determination, diligence, and practice, and I am striving to implement them into my life and into my career. 


\section{REFERENCES}

Euripides, The Bacchae and Other Plays. Trans. Philip Velacott. London: Penguin Group, 1954.

Tadashi Suzuki, The Way of Acting, The Theatre Writings of Tadashi Suzuki. Trans. J. Thomas Riner. New York: Theatre Communications Group, 1986. 


\section{CURRICULUM VITAE}

NAME: $\quad$ Julie Dingman Evans

ADDRESS : $252333^{\text {rd }}$ Street

Apt. 1A

Astoria, NY 11102

DOB: Jacksonville, Florida - March 20, 1969

EDUCATION \&

TRAINING :

B.F.A., Performing Arts, Dance Emphasis Western Kentucky University

1990-1993 